signal, low-noise channel for information on most scientific aspects of the solar system;

" $(b)$ by minimizing delay between the receipt of a communication and its publication to effect the promptness of communication essential in a so rapidly developing field of science;

" $(c)$ by inclusion of a bibliographical section covering all fields of interest to investigators of the solar system to ease the task of monitoring the information".

There are 35 associate editors, most of whose names are already well known. Their function is to collect papers and also to act as referees. It remains to be seen whether this arrangement will prove more successful than that of anonymous referees, whom we all find reasonably efficiont in dealing with the papers of other authors, although so tiresome with our own.

Fantastically great resources are at present being devoted to space research; but most of the effort is still being channelled into elaborate and lengthy preparations for difficult experiments, of which comparatively fow have yet had time to produce results. If all goes according to plan, ultimately, the amount of now material to be published and discussed may be very great. But so far, relative to the scale of the effort, the volume of results to reach the stage of publication is small (although this is not to minimize their significance). Clearly, Icarus has been started in the expectation of taking part in the harvest; but in common with other similar journals it must, for the present, rely chiefly on papers that could equally well have appeared in one or other of half a dozen existing periodicals. This at least seems true of Icarus, 1 , No. 1. It contains a long paper by A. G. W. Cameron discussing the problem of the formation of the Sun and planets, and three much shorter papers on the interplanetary medium, on the behaviour of photoelectrons emitted by solid bodies such as the Moon, and about the blue haze on Mars. There is also a letter discussing toroidal oscillations of the Moon.

Science is to-day more than ever in danger of sharing the fate of the Tower of Babel. However, the editors of Icarus believe that continued progress can be ensured by the formation of fresh, specialized sub-groups, each drawn from a fairly wide field of existing studies and provided with its own specialized journals. This kind of approach is not exactly new; it has been fruitful in the past and perhaps it promises better than any other. We are in a period of excessively rapid change in astronomy and in every other science connected with space research, affecting theories, instrumentation, administration, and ideas of all kinds, so that it is very difficult to say with confidence what policies are wisest. But so far as publications are concerned, I question whether existing journals are so overloaded that they cannot absorb comfortably all the papers on astronomy likely to result from space research for at least two or three years yet. By then we may be able to see the needs of the situation more clearly.

The financial problems of existing journals are not negligible, and the extra support of space researeh papers, should it lead to a greater circulation, as it probably would, might in most cases be very welcome. Further, I think it important that space research workers should know what is going on in the older astronomy, and that equally the older kind of astronomer should get to know about space research. Ton or fifteen years ago, after some initial fumbling, radio and optical astronomers discovered that they were better off together than apart, and now to a large extent publish their papers together in the same journals. I hope that this kind of development will come about in the case of astronomy conducted with rockets, artificial satellites, otc.

As to rapidity of publication, the average interval between receipt of manuscript and publication is slightly greater in Icarus, 1, No. 1, than in Monthly Notices of the Royal Astronomical Society, 124, No. 1, also dated May 1962, a journal now 135 years old, which still manages to cover most of astronomy at a satisfactory level of originality and technical quality.

The bibliography mentioned by the editors include 349 papers in this issue, the great majority from astronomical journals. They are classified, but no abstracts are given. Policy for this section of Icarus is still fluid, and one must wait for further issues before being able to judge whether there will be a distinctive service not yet provided by existing abstracting journals.

\section{R. O. Redman}

\title{
PLANNING NEW COMMUNITIES IN BRITAIN
}

\begin{abstract}
WHE report of the Carnegie United Kingdom Trust for 1960 gave some account of the study of the social problems of new communities in Britain which Dr. J. H. Nicholson had made at the request of the Trust and of the National Council for Social Service, and stated also that the Trust had set aside $£ 100,000$ in the new quinquennium, which opened in 1961, in order to promote pioneer projects in the provision of social amenities in new communities. The Trust has also appointed an Advisory Committee to consider applications, and where appropriate, to initiate action. Up to the end of 1961 no project, however, had been brought to the point of qualifying for a grant from this fund, practically all failing to measure up to the required standard of innovation. The fund is reserved for assisting work that is now on a national scale, and the Trust is prepared to wait for the right projects.
\end{abstract}

It is hoped that by the end of 1962 a pattern of expenditure will be planned which will provide assistance for promising projects in one or more of each type of new community in different geographical regions.

Dr. Nicholson's report was published in August $1961 *$, and the importance attached by the Carnegie United Kingdom Trust to this work is well indicated by the fact that in its report for $1961 \uparrow$ the Trust includes Dr. Nicholson's general recommendations in extenso as well as those on social development. His report is concerned with the now communities

* Nero Communities in Britain: Achievements and Problems. By J. H. Nicholson. Pp. 191. (London: The National Council of Social J. H. Nicholson. Pp. 191. (L

† The Carnegie United Kingdom Trust. 48th Annual Report, 1961. Pp. viii +76 . (Dunfermline, Fife: The Carnegie United Kingdom Trust, 1962.) (See also Nature, 195, 338; 1982.) 
on housing estates; in the fifteen new towns; in the planned extensions to certain small towns; and in the now housing estates built to replace slums now being domolished in the central areas of most largo cities. Dr. Nicholson directs most attention to the new towns, considering their housing problems and those of employment and services in separate chapters, and to the new towns as communities in a third chapter. Then he compares the four types of now communitios and discusses tho problems of community and leadership, assessing the factors which encourago the development of leadership and sources from which leaders are drawn.

These two chapters with their constructivo suggestions as well as critical analysis are probably the most valuable part of tho report, though Dr. Nicholson's clear account of the actual achievements, as well as his lucid assessment of the situation, should contribute to the public understanding of the real situation and needs of the new communities. Such an understanding, free from party political bias, is an almost indispensable pre-requisite to the formulation of the kind of proposals which the Carnegio Trust awaits.

For the rost, the general content of the report is well indicated by Dr. Nicholson's actual recommendations, which, as alroady noted, fall into two groups. Taking the genoral recommendations first, the new towns are producing a new typo of community, and this is likely to be true also of many expanded towns, For social provision gencrally, these new communities will be unablo oasily to draw on tho resources of personnol or material of the local authorities of the towns from which the population is being oxported. Dr. Nicholson recommends accordingly that the needs of the newcomers rather than the existing fractions of tho town or county should be the dominant consideration. A balancod community, with the optimum degree of self-containment, should bo envisaged from tho start and be the guiding principle in policy and planning. Future plans should provide for an adequate balance of ago-groups, and if this cannot be achieved initially, the master-plan should provide for the building of the necessary accommodation to redress the balance lator. $\Lambda n$ adequate varioty of types of accornmodation to offer an effoctivo choice between housos, maisonettes and flats is recommended, and to allow the possibility of purchase where desirod. The policy of providing employmont with housing should be continued and extendod, including further new towns and the possibility that one of the larger local authoritios, or two of them jointly, might build a now town.

Since the social structure of a community depends on the balance of occupations, a variety of industries and other kinds of employment should provide work for skillod and unskillod men, for women (full-time and part-time), and in particular, for juveniles. Employment in commerce, offices, service, industry and shops, and in professional occupations is especially important. It could be quostioned whether tho report lakes account of long-term trends in ornployment, particularly the diminishing amount of unskilled. labour that is likely to be roquired, and although this really lies outside the scope of Dr. Nicholson's inquiry, the social offects of technological change certainly roquire careful study in the light of the ncods of new communitios. Beyond this, Dr. Nicholson recommends that tho master-plan should provide for a town centro adequate to the needs of the community when fully developed, and the provision of servies--including mooting-places and other arnon. ities-should be related to the neighbourhoods and other planning units. The master-plan should also provide sites for natural oxpansion, for churches, meoting-places, public houses and placos of entertainment in each soction. These and adequate space earmarked for physical recroation, should be protected against 'infalling' with housing unless a comprehensive survey of social requiremonts shows they are no longer neoded for social purposes.

Nine recommendations on social development follow. First, services and amenities should bo provided concurrently with the houses, and great stress is laid on the need for the closest co-operation betwoen the country and the developing authority as to provision and timing. The nced for community services, outside the scope of the statutory sorvices, should be kept under constant review by statutory and volun. tary bodics. Provision should also be mado ahead of noods for a meeting-place suitable for small groups, capable of extonsion if and when larger accommodation is noeded and the nocessary finance to build and maintain has been securcd. Community dovelopmont should be fostercd in various ways; by canalizing action from representativo bodies such as community associations; appointing a social dovelopment officer in every new town and large estate, and neighbourhood workers in smaller estatos; by placing housing management in the hands of qualified officors able to make personal contact with tenunts; cstablishing as soon as possible the normal rango of social agencies, voluntary as well as statutory; providing in largor communities a joint centre for social workers with offices, meeting-room and shared services; and making evory offort to elicit leadership from within the cormmunity itself.

Further close considoration and experiment should be directed towards discovering the types of provision - typically in clubs-most likely to attract and hold adolescents, and use should be made of the experience of social workers trained in group work. Community and neighbourhood associations are making a major contribution to many new communities, particularly by providing in their centres a wide variety of loisure activities, and in tho expcrience they give in the techniques of domocratic self-governmont and leadership. The associations and their National Federation should continue to roview the organization and policies of tho rnovoment in the prosent situation in new communities, in particular considering how the neods of the communitios they serve can best bo ascertained and met, continuing and extending the training of full-time community centre wardens and part-time voluntary officers. The Churches should keep continually under review the balance between their own social activitios and the work of their mernbers in tho wider community. Close touch should be kept between the various authorities and agencies concerned in social devolopment at officer-level and those appointed to special dutios in this fiold should be consulted from tho planning stago onwards. The participation of the general community should bo sectured at local level through the community or neighbourhood association and at central level through a council of social sorvice. Further field surveys dealing with particular communities and particular probloms aro necded. It is hoped that the bodios which have sponsored and financed studios of social development will continue to do so, and that other bodies will join them in making possible the further exploration of this wide and important fiold. 